\title{
Chemical and sensory characteristics of pulp and peel 'cajá-manga' (Spondias cytherea Sonn.) jelly
}

\author{
Caracterização química e sensorial de geléia da casca e polpa de cajá-manga (Spondias cytherea Sonn.)
}

\author{
Ellen Silva LAGO-VANZELA ${ }^{1}$, Priscila RAMIN ${ }^{1}$, Marcelo Andrés UMSZA-GUEZ², \\ Ginaldo Vieira SANTOS ${ }^{3}$, Eleni GOMES ${ }^{4}$, Roberto DA SILVA ${ }^{5 *}$
}

\begin{abstract}
Cajá-manga (Spondias cytherea) is a fruit with intense aroma and a sweet sour taste, thus being very appreciated. Its peel, in spite of being more fibrous, is tender and many times consumed with the pulp. The peel is a part of foods normally discarded, but many times, it is rich in taste and fibers, representing an option at the elaboration of new foods. Since there are no reports in the literature on the use of cajá-manga peel for jelly making, this work had the purpose of developing and evaluating this product. Based on the results, it was noted that the peels presented higher contents of protein, lipids, ashes, food fiber, total carbohydrates and pectin, and lower content of moisture, when compared to the pulp. The peel and the pulp (control) jellies presented the following physical-chemical characteristics: moisture, 29.5 and $34.2 \%$; proteins, 0.19 and $0.27 \%$; lipids, 0.11 and $0.16 \%$; total sugars, 56.5 and $65.5 \%$; and total soluble solids, 69 and $66^{\circ}$ Brix, respectively. The sensory analysis indicated that the product elaborated from the peel presented satisfactory acceptance for all the assessed attributes: appearance, color, odor, texture, taste and global evaluation. It is concluded that the total substitution of the pulp by the peel in the formulation, results in a product with good nutritional value with no sensory damages.
\end{abstract}

Keywords: cajá-manga; jelly; fruit's peel.

\section{Resumo}

O cajá-manga (Spondias cytherea) é uma fruta com aroma intenso e sabor agridoce, sendo, por isto, bastante apreciado. Sua casca, embora mais fibrosa, é tenra e muitas vezes consumida juntamente com a polpa. A casca é uma parte do alimento normalmente desprezada, mas, muitas vezes, é rica em sabor e fibras, representando uma opção na formação de novos alimentos. Em função de não haver na literatura relato do aproveitamento da casca de cajá-manga para a elaboração de geleia, este trabalho teve por objetivo desenvolver e avaliar este produto. Através dos resultados, constatou-se que as cascas apresentaram maiores teores de proteína, lipídios, cinzas, fibra alimentar, carboidratos totais e pectina e menor teor de umidade em relação à polpa de cajá-manga. A geleia de casca e da polpa (controle) apresentaram as seguintes características físico-químicas: umidade, 29,5 e 34,2\%; proteínas, 0,19 e 0,27\%; lipídios, 0,11 e 0,16\%; açúcares totais, 56,5 e 65,5\%; e sólidos solúveis totais, 69 e $66^{\circ}$ Brix, respectivamente. A análise sensorial indicou que o produto elaborado a partir da casca apresentou aceitação satisfatória para todos os atributos avaliados: aparência, cor, odor, textura, sabor e avaliação global. Conclui-se que a substituição total da polpa por cascas na formulação resulta em produto de bom valor nutricional sem prejuízos sensoriais.

Palavras-chave: cajá-manga; geléia; casca de frutas.

\section{Introduction}

Worldwide, Brazil stands out as one of the main countries for fruits production and presents a potential to attend the increasing demand of the internal and external markets for fresh and processed fruits (NUNES, 2009). An example of this is the increase of more than eleven times in the exporting of fresh fruits, in the last fourteen years, moving from US\$ 54 million at the beginning of the 1990's to more than US\$ 642 million in 2007 (919 thousand tons) (ANDRIGUETO et al., 2008). In order to be able to keep and widen the international markets of fruit and its products, the country has explored its biodiversity. Native fruits of the northeastern region, which were once restricted to areas of spontaneous and sub-spontaneous occurrence, are being commercially explored and, being valued mainly, because of their taste and innovating aspect. Species such as soursop, mangaba, sapodilla, cajá, acerola, amongst others, are already becoming available, in natura and processed, in large supermarket shelves and freezers and represent a precious source of foods and richness to the country (LABRUNA, 2001). On the other hand, the lack of knowledge of the nutritious principles of foods, as well as foods partial use due to bad eating habits causes

\section{Received 23/7/2009}

Accepted 18/1/2010 (004208)

${ }^{1}$ Laboratório de Bioquímica e Microbiologia Aplicada, Universidade Estadual Paulista - UNESP, Campus de São José do Rio Preto

2 Serviço Nacional de Aprendizagem Industrial - SENAI, Área Alimentos e Bebidas Departamento Regional da Bahia, Salvador, Bahia - BA, Brasil

${ }^{3}$ Departamento de Engenharia de Alimentos, Universidade Estadual Paulista - UNESP, Campus de São José do Rio Preto

${ }^{4}$ Departamento de Biologia, Universidade Estadual Paulista - UNESP, Campus de São José do Rio Preto

${ }_{5}$ Departamento de Química e Ciências Ambientais, Universidade Estadual Paulista - UNESP, Campus de São José do Rio Preto, Rua Cristóvão Colombo, 2265,

Jd. Nazareth, CEP 15054-000, São José do Rio Preto - SP, Brasil, E-mail: dasilva@ibilce.unesp.br

${ }^{*}$ Corresponding author 
the waste of tons of food resources every year in Brazil (FOOD..., 2004; RUSS; SCHNAPPINGER, 2007). The consequences are the irrecoverable economic losses, unbalanced supply and food price increase, which reflect negatively on the resources that the population needs to have nutrition with adequate quality and quantity (BORGES, 1991; GONDIM et al., 2005).

Facing this problem, many segments of society and several national institutions have started to act towards the reduction of hunger and malnutrition by combating waste of food. Among the ongoing campaigns, two have been gaining strength in the past years: the development of products from non-conventional fruits and the utilization of parts of industrialized fruits that are underused (LAUFENBERG; KUNZ; NYSTROEM, 2003). Peels from some ripe fruits, for example, in spite of presenting high nutritional value, are discarded by the food industries (SCHIEBER; STINTZING; CARLE, 2001). Therefore, they can be used as raw material for the elaboration of dough, sweets, cakes, juices and jellies (DAMIANI et al., 2009; GONDIM et al., 2005; MIGUEL et al., 2008; OLIVEIRA et al., 2002). Among the diversity of fruits found in Brazil, the cajá-manga in particular, presents ellipsoidal shape and, when ripe, its pulp is succulent, aromatic and with a sour sweet taste, slightly acid, where there is a seed with a fibrous and rigid structure. Both peel and pulp present carotenoids, responsible for their attractive orange color (ROSSO et al., 2008). Also known as cajarana, this fruit is found in the tropical areas of Latin America and countries of the Caribbean, where it is cultivated and exported to Europe (BAUER; KIM, 1992). Found in the North and Northeastern regions of the country, this fruit is consumed in natura and can be used to elaborate juices, ice cream, jellies and fruit preserves (LORENZI et al., 2006), what has aroused the interest of researchers and processing industries. Products made from the fruit seem like an interesting option, since they present suitable sensorial and nutritional properties (ROSSO et al., 2008; UNIVERSIDADE..., 2006), which meet the tendencies established by consumers searching for healthy products with differentiated tastes (SCHIEBER; STINTZING; CARLE, 2001). Also, the peels represent a part of the food that is normally discarded, but a lot of times, it is rich in flavor, nutrients and fiber (DAMIANI et al., 2009; MIGUEL et al., 2008; SCHIEBER; STINTZING; CARLE, 2001). Since there is no report in the literature of the use of the cajá-manga peel for jelly making, this work had the purpose of developing this product and evaluating its physical-chemical and sensory characteristics and comparing it to the jelly obtained with the pulp (conventional jelly).

\section{Materials and methods}

\subsection{Raw material and ingredients}

The fruits were acquired at local markets in Sao Jose do Rio Preto, Northwest region of the State of Sao Paulo, during the harvest season in 2008, they were transported to the Biochemistry and Applied Microbiology Laboratory UNESP - Sao Paulo State University, Sao Jose do Rio Preto campus. They were selected, washed in running water using a sponge for appropriate cleaning of the peels, treated in a solution of sodium hypochlorite $\left(200 \mathrm{mg} \cdot \mathrm{L}^{-1}\right)$ for 15 minutes, rinsed, conditioned in plastic sacks and maintained under refrigeration $\left(5-7^{\circ} \mathrm{C}\right)$. The following ingredients and addictives were used for the elaboration of jelly: sucrose (Cristal); glucose (Doce Aroma), citric acid (Doce Aroma) and two types of pectin (donated by CPKelco with SAG units of 150): one with semi-rapid gelification (GENU Pectin Type 115, with metoxilation range between 66-70\%), and another with rapid gelification (GENU Pectin Type 105, with metoxilation range between $70-76 \%)$.

\subsection{Partial physical-chemical characterization of the fruits}

Fruits from three different lots were peeled and separated from the seed using a stainless steel knife. The yield of pulp and peel were calculated by the ratio between the weight of the whole fruit and the weight of peel, seed and pulp. Portions representing each lot, regarding the fruit peel and pulp, were separated for chemical analysis. The remaining samples were used for jelly processing. Pulp and peel portions were homogenized in an industrial stainless steel blender with $2 \mathrm{~L}$ capacity (Tron), with velocity of 25,000 rpm when empty. The following analysis were carried out: protein content, lipid content, ashes content, $\mathrm{pH}$, total soluble solids ( $\left.{ }^{\circ} \mathrm{Brix}\right)$, total titratable acidity (direct titration in citric acid), total pectin and moisture content, according to 'Instituto Adolfo Lutz' (PREGNOLATTO; PREGNOLATTO, 1985). Total sugar was obtained by calculating the difference between other fractions (proteins, lipids and ashes) and total dietary fiber was determined according to GUERRA et al. (2004).

\subsection{Jelly processing}

\section{Cajá-manga pulp jelly}

The following proportion of pulp was used: water of 0.5:0.5 $(\mathrm{v} / \mathrm{v})$. After dilution, sugar was added in the proportion of $0.8: 0.2$ of pulp:sugar (sugar in the proportion of sucrose:glucose of $0.8: 0.2, \mathrm{w} / \mathrm{w}$ ) and $1.3 \%$ of pectin (pectin in the proportion of type 105:type 115 of $0.7: 0.3, \mathrm{w} / \mathrm{w}$ ).

\section{Cajá-manga peel jelly}

Peels were homogenized with water in the proportion of $1: 2, \mathrm{w} / \mathrm{w}$, and subjected to boiling for 5 minutes. This mixture was filtered in a 0.58 mesh sieve and the extracted obtained was reserved for jelly making. Sugar was added to the extract in the proportion of 0.2:0.8 (sugar in the proportion of sucrose:glucose of $0.8: 0.2$ ) and $1.0 \%$ of pectin (pectin in the proportion of type 105:type 115 of 0.7:0.3, w/w). Both jellies were submitted to cooking in stainless steel pan with $5 \mathrm{~L}$ capacity, with continuous manual stirring until the desired final soluble solids concentration was reached. The total soluble solids were measured using a refractometer (Abbe Modelo 2 Waj, Biobrix). After that, the jellies were packed, still hot, in glass jars with 250 g capacity, previously sterilized at $121{ }^{\circ} \mathrm{C} / 15$ minutes, closed with metal caps, immediately cooled by addition of cold water for 15 minutes and maintained at room temperature. 


\subsection{Physical and chemical determinations of jellies}

The jellies were analyzed regarding protein content, lipid content, $\mathrm{pH}$, total soluble solids ( ${ }^{\circ}$ Brix), total titratable acidity (direct titration, in citric acid) and moisture content, according to 'Instituto Adolfo Lutz' (PREGNOLATTO; PREGNOLATTO, 1985). Total sugar was determined according to Dulbois et al. (1956), reducing sugars according to Miller (1959) and non-reducing sugars, by the difference between the last two. The sample colors were estimated by taking pictures of the samples with a digital camera (Mitsuca DC 7325BR, 3.0 megapixels) and the digitalized pictures were analyzed using the software LensEye V-01 (Engineering \& Cyber-Solutions, Gainesville, FL-USA). The parameters used for the evaluation of jelly color were the coordinates $L^{*}$ (luminosity), $a^{*}$ (red versus green) and $b^{\star}$ (yellow versus blue), following the CIELAB color scale. All assays were carried out in triplicate. To avoid external interference on the sample colors, the pictures were taken into a chamber assembled according to the suggested design of Luzuriaga et al. (1997).

\subsection{Sensory analysis of the jellies}

The affective test for acceptability was carried out with 100 potential fruit jelly consumers, chosen according to interest, availability to participate in the tests and their jelly consumption frequency. The analyses were carried out in individual cabins at the Sensorial Laboratory at Food Engineering Department of UNESP, Sao Jose do Rio Preto campus. Samples of approximately $25 \mathrm{~g}$ were served randomly to the panelists in plastic recipients identified with 3-digit codes. The panelists were asked to indicate how much they liked/disliked the jellies based on the following attributes: appearance, color, odor, texture, taste and global evaluation, according to a 9-point hedonic scale ( $1=$ dislike extremely; 2 = dislike very much; 3 = dislike moderately; 4 = dislike slightly; 5 = neither like nor dislike; 6 = like slightly; 7 = like moderately; 8 = like very much; 9 = like extremely).

To be certain that the differences in appearance of the samples could not influence the panelists' answers, the evaluation of color and appearance attributes were carried out under white light and the other attributes (odor, texture and taste) under red light. Means of the attributes referring to the preference of the evaluated samples were complemented by descriptive statistical analysis of the standard deviations and variation coefficients. This research was submitted and approved by the Ethics in Research Committee from UNESP/ IBILCE (Report N ${ }^{\circ} 36 / 09$ and Certificate of Presentation for Ethic Appreciation $\left.-\mathrm{N}^{\circ} 0010.0 .229 .000-09\right)$ and the participants signed a Term of Consent, according to Resolution 196/96, which contains the policies and regulations for researches involving human beings (FARIA; YOTSUYANAGI, 2008).

\section{Results and discussion}

\subsection{Raw material yield}

Yield of pulp, peel and seed were of approximately 69, 15 and $13 \%$, respectively. The results were similar to the ones reported by Sousa et al. (2005), who found 65\% of pulp yield, and greater than the reported by Suzuki et al. (2007), who found a yield of $24 \%$. Sacramento and Souza (2000) observed that cajá, presented a yield percentage of peel and pulp with a variation between 8 and 19\%, and between 16 and 46\%, respectively. For umbu-cajá, Silva Junior et al. (2004) verified that the yield percentage of pulp was between 55 and $67 \%$. It is possible to observe that cajá-manga presents more similarity to the physical characteristics of umbu-cajá. It is known that fruits destined to the elaboration of products such as juices, wines, jellies and sweets must present a minimal yield of $40 \%$ to be accepted by the processing industries (OLIVEIRA et al., 1999). Therefore, these results indicate that cajá-manga is suit for processing and that this yield could be even higher (87\%) if the peel is used along with the pulp for product elaboration.

\subsection{Chemical characteristics of peel and pulp from cajá-manga}

Centesimal composition of a fruit can usually be determined by preparing the sample the same way it is consumed, which could be with the peel or peeled. Cajá-manga can be consumed both ways. In this case pulp and peel were analyzed separately (Table 1). Similarly to most vegetable products, the pulp of this fruit presented moisture content ranging from 74 to $94 \%$ (ALAIS; LIDEN apud SOARES et al., 2001). The value found was close to the one described for the fruit in the Brazilian Food Composition Table - TACO (UNIVERSIDADE..., 2006) (86.7\%) and lower than the one found by Donadio et al. (1998) (72.6\%). Fruits such as soursop (82.2\%), abiu (83.1\%), Haden mango (82.3\%) and Argentine apple (82.6\%) (UNIVERSIDADE..., 2006) present moisture content similar to cajá-manga. After peel analysis, it was observed that the moisture content was $11 \%$ lower than the one found for the pulp. Similar results were observed by Gondim et al. (2005) when analyzing moisture content of avocado pulp and peel ( 84 and $77 \%$, respectively) and pineapple (86 and 78\%, respectively) and by Damiani et al. (2009) who reported a moisture content of mango pulp and peel 81,98 and $77,41 \%$, respectively. However, Gondim et al. (2005) showed that not all fruits present this type of behavior. This probably occurs due to the different morphological characteristics of pericarps (BARROSO et al., 1999) and to the ripening stage of the fruits, knowing that the ripening process may lead to moisture loss

Table 1. Chemical determinations of cajá-manga pulp and peel*.

\begin{tabular}{lcr}
\hline \multicolumn{1}{c}{ Determinations } & \multicolumn{2}{c}{ Cajá-manga } \\
\cline { 2 - 3 } & $82.80 \pm 0.19^{\mathrm{a}}$ & $73.54 \pm 0.04^{\mathrm{b}}$ \\
\hline Moisture (\%) & $1.01 \pm 0.02^{\mathrm{a}}$ & $1.47 \pm 0.00^{\mathrm{b}}$ \\
Protein (\%) & $0.23 \pm 0.01^{\mathrm{a}}$ & $0.85 \pm 0.02^{\mathrm{b}}$ \\
Lipids (\%) & $0.39 \pm 0.01^{\mathrm{a}}$ & $0.98 \pm 0.02^{\mathrm{b}}$ \\
Ash (\%) & $1.40 \pm 0.01^{\mathrm{a}}$ & $1.70 \pm 0.01^{\mathrm{b}}$ \\
Total dietary fiber (\%) & $14.19 \pm 0.02^{\mathrm{a}}$ & $21.47 \pm 0.02^{\mathrm{b}}$ \\
Carbohydrates (\%) & $0.50 \pm 0.01^{\mathrm{a}}$ & $0.85 \pm 0.01^{\mathrm{b}}$ \\
Acidity (\%) (in citric acid) & $3.32 \pm 0.01^{\mathrm{a}}$ & $2.78 \pm 0.02^{\mathrm{b}}$ \\
pH & $0.53 \pm 0.02^{\mathrm{a}}$ & $2,49 \pm 0.02^{\mathrm{b}}$ \\
Total Pectin (\%) & \multicolumn{2}{c}{ Pulp } \\
* Values followed by the same letter on the same row do not differ significantly by the \\
Tukey test (p<0.05). Means of the values obtained after analysis of the three lots of fruits.
\end{tabular}


and, as a result, to a concentration of the other constituents (PINHEIRO, 2007).

Lipid and protein content for the pulp exhibited higher and lower variations when compared to the values reported for the same fruit in Taco (UNIVERSIDADE..., 2006) (traces and $1.3 \%$, respectively) and found by Donadio et al. (1998) ( 0.35 and $0.25 \%$, respectively). These results are very close to the contents reported for acerola, atemóia, cashew and figs (UNIVERSIDADE..., 2006). When comparing protein content found in the pulp of cajá-manga to the one found in the peel, it was seen that the profile is very similar to what is presented for papaya, avocado and pineapple (GONDIM et al., 2005), with the contents of the peel being greater than the contents of the pulp for all fruits. Lousada Junior et al. (2006) had already reported that the sub-products of processed fruits - including peels - are, in general, important protein sources and that the variations of protein contents among the same species may occur due to differences in cultivation conditions such as soils and fertilizers (especially the ones containing nitrogen), which may alter the protein content in fruits.

Lipids, however, are highly energetic molecules and generally appear in small amounts in fruits and vegetables. The lipid content of the peel was also higher than the pulp and, these results were similar to the one reported for many other fruits (passion fruit, melon, tangerine, avocado, pineapple, banana and papaya) (GONDIM et al., 2005). These fruits also exhibit ash content similar to cajá-manga pulp, varying between $0.3-0.4 \%$ (UNIVERSIDADE..., 2006). On the other hand, the ash content for cajá-manga peel was considerably higher when compared to the value for the pulp and was similar to the values presented for melon and banana peel (0.96\% and $0.95 \%$, respectively) (GONDIM et al., 2005).

Dietary fiber percentage found for pulp was considerably lower than what is reported in Taco (UNIVERSIDADE..., 2006) (2.6\%), and close to the percentage for acelora (1.5\%), Haden mango (1.6) and peach (1.4\%) (UNIVERSIDADE..., 2006). Variations in the centesimal composition can be, probably, attributed to differences in the extent of ripening of the fruits, cultivation region, cultivars, storage conditions, weather conditions during plantation and even to analysis methodologies. The influence of these factors had already been reported by Suzuki et al. (2007), after partial determination of the centesimal composition of cajá-manga pulp.

The fiber content of the peel was greater than the one found for the pulp and presented a very similar profile to the one for banana (GONDIM et al., 2005). Rocha et al. (2008) also determined the value of fibers and lipids of different peels from fruits and vegetables. The results showed reasonable contents, or even higher than many parts of fruits commonly consumed. Based on the fiber content found in cajá-manga peel, its use as flour or a study of other products aimed at people that need to increase fiber intake can be suggested. However, attention should be given to the fact that dietary fibers found in pulps and peels from fruits present, in a general way, very distinct characteristics. The insoluble fractions are the main ones found in fruits peels, made up especially of lignin, protopectins, cellulose and other hemicelluloses. However, in pulp, soluble fractions are predominately found, made up of pectin, betaglucans, gums, mucilages, polysaccharides and hemicelluloses (JORGE; MONTEIRO, 2005). These fractions present different functions on the organism's metabolic balance, and it is necessary to gather more knowledge about its benefits and toxicity, so that the population can use it adequately (GONÇALVES et al., 2007).

In fruits destined to jelly making, the fibers of most interest are pectins, due to their gelifying and stabilizing properties. The results from centesimal composition show that the pulp presents pectin content $(0.53 \%)$ considerably lower than the peel $(2.49 \%)$. Rodrigues et al. (2008) found pectin content for cajá-manga pulp (2.66\%) significantly different from the one we reported, but close to the content of the peel. The pectin content for the peel is close to the one found in cacao peel $(2.73 \%)$ and lower than the ones reported for passion fruit peel (7.18\%), Tommy (3.50\%) and Palmer (3.44\%) mango and Kiwano (3.34\%).

The carbohydrate content of the pulp was greater than the one found in Taco (UNIVERSIDADE..., 2006) (11.4\%) and close to other fruits, such as abiu (14.9\%), plum (13.9\%), macaúba (13.9) and pear (14.0\%) (UNIVERSIDADE..., 2006). Due to the lower moisture level, the peel exhibited greater carbohydrate content than the pulp. Both pulp and peel of cajámanga exhibited low $\mathrm{pH}$ and relatively high acidity and they were similar to the values presented by Donadio et al. (1998). When comparing the centesimal composition of peel and pulp, it could be seen that the nutrients contents were significantly higher in the peel, what reinforces the importance of using the whole fruit for jelly making. The results show that both pulp and peel present sweet and acid tastes and that the peel contributes in a significant way to the pectin content - these are interesting characteristics for jelly making.

\subsection{Adequacy of the conventional technology for cajá-manga peel and pulp jelly processing and its physical and chemical characteristics}

Initially, some jelly formulations were tested aiming to find proportions of fruit parts:sugar (sucrose) that resulted in extra type jelly with taste similar to the fruit. After determining these proportions (listed in item 2.3), we opted to replace $20 \%$ of the sucrose by glucose to increase the brightness of the products. It was observed that the pectin contents of cajá-manga pulp and peel were not sufficient for gel formation. This fact explains the addition of commercial citric pectin for jelly making.

The pectins used in the formulations were chosen based on the $\mathrm{pH}$ of the pulp and/or extract, on the soluble solids content and on the product filling temperature. First, the use of $1.3 \%$ and $1 \%$ of Pectin GENU type 105, of rapid gelification, was tested for jelly made from pulp and peel, respectively. The percentages of pectin tested were determined according to the pectin content of the parts of the fruits used for jelly making and on the levels of SAG units of the pectins, which represent the number of grams of sucrose capable of gelyfiyng one gram of pectin, resulting in a gel with standardized consistency in conditions pre-determined by the manufacturer (JACKIX, 1988). 
It is known that high metoxilation pectins demand a specific temperature range in which gel formation is favorable during the cooling process (RIBEIRO; SERAVALLI, 2004). In the artisanal processing scale, the long filling step period decreases jelly temperatures $\left(80^{\circ} \mathrm{C}\right)$ to values not recommended for Pectin GENU type 105 , which is of $85^{\circ} \mathrm{C}$, damaging the execution of this step of the process. According to Soler (1991), the solution to this problem would be to increase the temperature during the bottling step or to opt to slower gelification pectin. Then, the use of Pectin GENU type 115, of semi-rapid gelification at $75^{\circ} \mathrm{C}$ was tested at the same previously used proportions. In spite of pectins that form gel at lower temperatures, with intermediate speed, be interesting for artisanal processes, the use of only Pectin GENU type 115 also did not result in adequate gel formation.

A combination of the two pectins in the proportion type 105 : type 115 of 0.7:0.3 (w/w) was used. In spite of the difference in the gelifying temperature between the tested products be small $\left(5^{\circ} \mathrm{C}\right)$, the metoxilation level of the pectins has a direct influence on functional properties such as solubility, capacity and conditions of gelifying (LICODIEDOFF, 2008). The association of these pectins probably provided enough time for the handling during the filling and cooling steps, resulting in jellies with better texture. Thus, for both jellies, the use of Pectin GENU type 105 was chosen, combined with slower gelifying pectin (Pectin GENU $115)$ in the proportion of 0.7:0.3 (w/w), respectively.

In a general manner, the acidification of the mixture (pulp and/or extract, sugar, pectin) for jelly making, if necessary, must be carried out at the end of the concentration process, before filling, in order to avoid destructing the pectin and the consistency of the formed gel (ALMEIDA; SCHMIDT; GASPARINO FILHO, 1999). Fruit pulp presented pH 3.3, while the extract obtained from the peel presented $\mathrm{pH} 2.8$. It is known that optimum $\mathrm{pH}$ for gel formation varies between 3.0 and 3.4 as a function of the final soluble solids content of the jelly (JACKIX, 1988). However, we decided to make the jelly at the pulp natural $\mathrm{pH}$ to avoid introducing additives to the formulation. A similar situation was found by Bispo (1989) and Folegatti et al. (2003) when developing umbu jelly: in the first study, although the pulp presented high acidity $(1.23 \%$, in citric acid) and $\mathrm{pH} 2.45$, the product was developed and presented $\mathrm{pH} 2.37$ and acidity of $0.55 \%$; in the second study, the pulp used for jelly processing presented $\mathrm{pH} 2.82$ and total titrated acidity of $1.56 \%$ and resulted in jellies with $\mathrm{pH}$ between 2.82 and 3.05 , acidity between 0.62 and $0.88 \%$ and sweetness, acidity and firmness close to the ideal.

The acidity of the extract of cajá-manga peel did not strongly interfere on gel formation and a jelly with $\mathrm{pH}$ close to the one found for araçá-boi jelly ( $\mathrm{pH} 3.10)$ was obtained Chisté et al. (2008). On the other hand, this acidity resulted in the hydrolysis of non-reducing sugars present in the jelly. This type of hydrolysis had already been reported in a study on the behavior of physical chemical characteristics of light blackberry jelly during storage (NACHTIGALL et al., 2004). The jelly elaborated from cajá-manga pulp presented $\mathrm{pH}$ close to the one found for blackberry (pH 3.26) (MOTA, 2006, 2007), however, a little lower than pineapple (pH 3.50) (GRANADA et al., 2005) and cashew (pH 3.56) (ASSIS et al., 2007). The highest reducing sugar content gave the jellies a more shiny aspect and probably reduced their sweetness. From Table 2 it can be seen that the jelly made with peel presented lower total sugars content and, consequently, tasted not as sweet as the conventional jelly. The mean of the values for moisture and total soluble solids content for both products was within the range found for most jellies, that is, $38 \%(\mathrm{p} / \mathrm{p})$ at maximum and $62^{\circ} \mathrm{Brix}(\mathrm{p} / \mathrm{p})$ at minimum, respectively.

A similar result was also found by Miguel et al. (2008) after developing melon peel jelly, with total soluble solids content of $68{ }^{\circ}$ Brix and a moisture content of $29.78 \%$. However, Damiani et al. (2009), after evaluating the quality of jellies formulated with $0,25,50,75$ and $100 \%$ of mango (Mangifera indica L. cv. Haden) pulp substitution for peel, observed that the soluble solids content (62-62.5 ${ }^{\circ}$ Brix) and the moisture content (35.10-37.58\%), from all treatments, were in agreement with the legislation. Nevertheless, the authors verified that an increase of over $50 \%$ of pulp in the formulation may decrease shelf life, once the high moisture content accounts for easier growth of filamentous fungi and yeasts.

Although cajá-manga peel presented higher lipid and protein contents than the pulp, peel jelly presented lower contents of these compounds, when compared to the ones presented for pulp jelly. Damiani et al. (2009) observed an increase in the protein content after incorporating mango peel to the jelly formulation. However, the authors reported a noticeable decrease of these contents when compared to the in natura fruit. According to Barcelos and Ferrua (2003), when submitting foods to heat processing, it is common to have a decrease in the protein content due to protein degradation. Another explanation may be due to the higher acidity of the peel, which under heating contributes to protein hydrolysis.

The results reported by Damiani et al. (2009) also showed that the lipid content of the raw material (mango pulp and peel) was reduced during processing, especially in the ones formulated with higher peel contents. The reduction can be explained by complex reactions with other components of the pulp, such as lipid oxidation in the presence of oxygen, heat, light and high water activity during jelly processing steps. (ANDRADE, 2006).

Through color analysis of the fruit, it was possible to observe that the use of the peel as raw material for jelly elaboration caused a significant decrease in the luminosity value $\left(L^{*}\right)$. On the other hand, a significant increase in the values of intensity of the color red, as observed by $a^{\star}$ (red versus green) and $b^{\star}$ (yellow versus blue) values; this is probably due to the fact that the peel has higher pigment content than the pulp. Peels from several fruits present pigment content greater than the pulp, such as in most grape cultivars (FERNÁNDEZ-LÓPEZ et al., 1998) and in cajá (RODRIGUEZ-AMAYA et al., 2008).

\subsection{Sensory analysis of the jellies}

The results shown in Table 3 reveal that the jelly made from the peel presented significantly better scores in the attributes appearance, taste and global evaluation. The fruit differentiated 
Table 2. Chemical determinations of cajá-manga pulp and peel jellies*.

\begin{tabular}{lcc}
\hline \multirow{2}{*}{ Determination } & \multicolumn{2}{c}{ Jelly made from } \\
\cline { 2 - 3 } & \multicolumn{1}{c}{ Pulp } & Peel \\
\hline Moisture (\%) & $34.2 \pm 0.14^{\mathrm{a}}$ & $29.5 \pm 0.23^{\mathrm{b}}$ \\
Protein (\%) & $0.27 \pm 0.02^{\mathrm{a}}$ & $0.19 \pm 0.01^{\mathrm{b}}$ \\
Lipids (\%) & $0.16 \pm 0.00^{\mathrm{a}}$ & $0.11 \pm 0.00^{\mathrm{b}}$ \\
Total sugars (\% glucose) & $65.5 \pm 0.45^{\mathrm{a}}$ & $56.5 \pm 0.34^{\mathrm{b}}$ \\
Reducing sugars (\% glucose) & $50.9 \pm 0.30^{\mathrm{a}}$ & $44.5 \pm 0.29^{\mathrm{b}}$ \\
Non-reducing sugars (\% sucrose) & $14.6 \pm 0.21^{\mathrm{a}}$ & $12.1 \pm 0.09^{\mathrm{b}}$ \\
Total soluble solids ( ${ }^{\circ}$ Brix) & $66.0 \pm 0.43^{\mathrm{a}}$ & $69.0 \pm 0.51^{\mathrm{b}}$ \\
Acidity (\%) (in citric acid) & $0.98 \pm 0.01^{\mathrm{a}}$ & $1.75 \pm 0.02^{\mathrm{b}}$ \\
pH & $3.28 \pm 0.02^{\mathrm{a}}$ & $3.09 \pm 0.00^{\mathrm{b}}$ \\
Color $L^{*}$ & $81.2 \pm 0.56^{\mathrm{a}}$ & $73.2 \pm 0.32^{\mathrm{b}}$ \\
Color $a^{*}$ & $14.2 \pm 0.02^{\mathrm{a}}$ & $23.3 \pm 0.01^{\mathrm{b}}$ \\
Color $b^{*}$ & $69.2 \pm 0.12^{\mathrm{a}}$ & $75.6 \pm 0.43^{\mathrm{b}}$ \\
\hline
\end{tabular}

* Values followed by the same letter on the same row do not differ significantly by the Tukey test $(\mathrm{p}<0.05)$.

Table 3. Sensory characteristics of cajá-manga jellies. *

\begin{tabular}{lccc}
\hline \multicolumn{1}{c}{ Attributes } & \multicolumn{2}{c}{ Jellies } & MSD \\
\cline { 2 - 3 } & peel & pulp & \\
\hline Appearance & $6,24 \pm 1,74^{\mathrm{a}}$ & $5,71 \pm 1,71^{\mathrm{b}}$ & 0,04 \\
Color & $6,66 \pm 1,75^{\mathrm{a}}$ & $6,56 \pm 1,45^{\mathrm{a}}$ & 0,02 \\
Odor & $6,42 \pm 1,41^{\mathrm{a}}$ & $6,26 \pm 1,52^{\mathrm{a}}$ & 0,01 \\
Texture & $6,35 \pm 2,03^{\mathrm{a}}$ & $5,78 \pm 2,04^{\mathrm{a}}$ & 0,07 \\
Taste & $7,19 \pm 1,29^{\mathrm{a}}$ & $6,49 \pm 1,67^{\mathrm{b}}$ & 0,02 \\
Global Evaluation & $7,06 \pm 1,17^{\mathrm{a}}$ & $6,26 \pm 1,40^{\mathrm{b}}$ & 0,02 \\
\hline
\end{tabular}

* Values followed by the same letter on the same row do not differ significantly by the Tukey test $(\mathrm{p}<0.05)$.

Table 4. Percentage of acceptance, indifference and rejection of cajámanga jellies.

\begin{tabular}{crc}
\hline Acceptability & \multicolumn{2}{c}{ Jellies } \\
\cline { 2 - 3 } Appearance & peel & pulp \\
Acceptance & 70,71 & 56,57 \\
Indifference & 8,08 & 13,13 \\
Rejection & 21,21 & 30,30 \\
Color & & \\
Acceptance & 74,75 & 78,79 \\
Indifference & 11,11 & 13,13 \\
Rejection & 14,14 & 8,08 \\
Odor & & \\
Acceptance & 69,70 & 66,67 \\
Indifference & 24,24 & 22,22 \\
Rejection & 6,06 & 11,11 \\
Texture & & \\
Acceptance & 65,66 & 66,67 \\
Indifference & 10,10 & 14,14 \\
Rejection & 24,24 & 29,29 \\
Taste & & \\
Acceptance & 90,91 & 19,19 \\
Indifference & 4,04 & \\
Rejection & 5,05 & \\
\hline
\end{tabular}

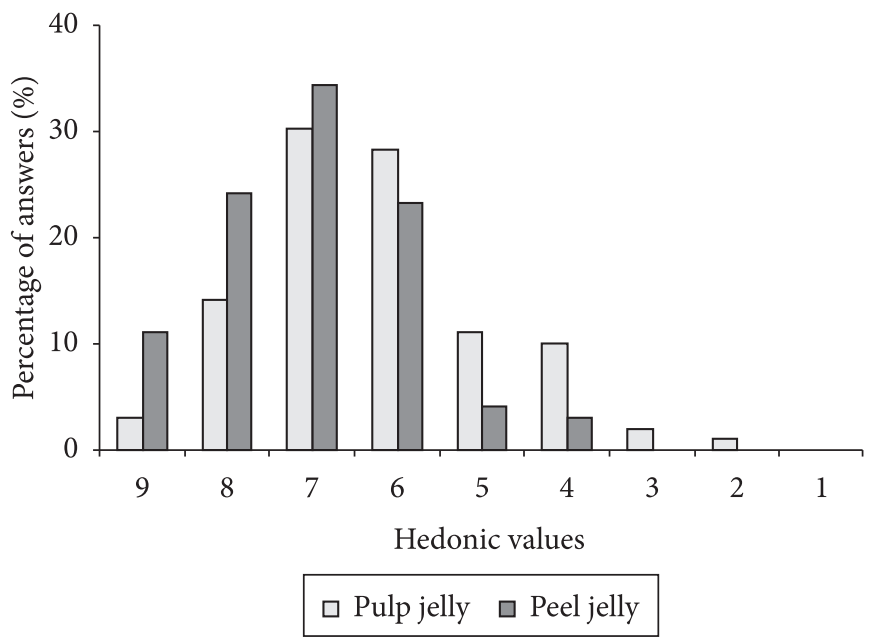

Figure 1. Histograms of the frequency of hedonic values regarding global evaluation of the jellies; $9=$ like extremely, $5=$ neither like nor dislike, 1 = dislike extremely).

taste may have been intensified by the high acidity of the peel and contributed to the jelly better acceptance of taste and global evaluation. Observing Table 2, it can also be seen that all the evaluated attributes resulted in considerably high standard deviations; this is a common fact among consumers' tests, which generally exhibit differences related to the level of liking or disliking the tested samples.

In terms of global evaluation, both jellies presented a sensory profile almost totally situated in the region of acceptance, with maximum of answers in the category 'like regularly' (7 score) (Figure 1). Correlating these data with the percentage of acceptance, indifference and rejection presented on Table 4, it can be seen that the use of cajá-manga peel as an ingredient for jelly-making positively contributed to the sensory quality of the final product. Besides, this new product aggregates value to the fruit and makes the nutrients available for a longer period of time, as it was also observed after elaboration of jambolan fruit jelly (LAGO; GOMES; DA-SILVA, 2006). The results revealed good perspectives to broaden native fruit application in the food industry.

\section{Conclusions}

The chemical compositions were different: the peels presented higher contents of protein, lipids, ashes, food fiber, total carbohydrates and pectin, and lower contents of moisture than the pulp. Jelly made from cajá-manga peel presented taste and aroma characteristic of the fruit and palatability very similar to the conventional jelly. Thus, both materials exhibited potential for jelly processing. In special, the peel can become an option for the utilization of underused food resources with important nutritional properties. These raw materials constitute a new option for the agro-industries that seek to maintain and widen international markets of fruits and their products.

\section{Acknowledgments}

The authors are grateful to CAPES for the student's grant and to $\mathrm{CNPq}$ for the productivity scholarship. 


\section{References}

ALMEIDA, M. E. M.; SCHMIDT, F. L.; GASPARINO FILHO, J. Processamento de compotas, doces em massa e geléias: Fundamentos básicos. Campinas: ITAL/FRUTHOTEC, 1999. p. 62. (Manual Técnico, n. 16).

ANDRADE, E. C. B. Análise de Alimentos: uma visão Química da Nutrição. São Paulo: Livraria Varela, 2006. p. 238.

ANDRIGUETO, J. R. et al. Produção integrada de frutas e sistema agropecuário de produção integrada no Brasil. Disponível em: $<$ http://www.foodservicenews.com.br/materia.php?id=74>. Acesso em: 26 set. 2008 .

ASSIS, M. M. M. et al. Processamento e estabilidade de geléia de caju. Revista Ciência Agronômica, v. 38, n. 1, p. 46-51, 2007.

BARCELOS, M. F. B.; FERRUA, F. Q. Frutas e hortaliças processados: métodos de conservação e efeitos no valor nutritivo. Lavras: UFLA/ FAEPE, 2003.

BARROSO, G. M. et al. Frutos e sementes: morfologia aplicada à sistemática de dicotiledôneas. Viçosa: Ed. UFV, 1999.

BAUER, T.; KIM, J. The golden apple (Spondias dulcis Forst.) in the west indies: research, development and markets. InterAmerican Society Tropical Horticulture, v. 36, p. 26-35, 1992.

BISPO, E. S. Estudo de produtos industrializáveis do umbu (Spondias tuberosa, Arr. Câmara). 1989. 119 f. Dissertação (Mestrado em Tecnologia dos Alimentos)-Universidade Federal do Ceará, Fortaleza, 1989.

BORGES, R. F. Panela Furada: o incrível desperdício de alimentos no Brasil. 3. ed. São Paulo: Columbus, 1991.

CHISTÉ, R. C. et al. Caracterização físico-química, microbiológica e sensorial de geléia elaborada com araçá-boi (Eugenia stipitata Mc Vagh). Disponível em: $<$ http://artigocientifico.uol.com.br/uploads/ artc_1164771983_88.pdf>. Acesso em: 20 set. 2008.

DAMIANI, C. et al. Avaliação química de geléias de manga formuladas com diferentes níveis de cascas em substituição à polpa. Ciência e Agrotecnologia, v. 33, n. 1, p. 177-184, 2009. http://dx.doi. org/10.1590/S1413-70542009000100025

DONADIO, L. C.; NACHTIGAL, J. C.; SACRAMENTO, C. K. Frutas exóticas. Jaboticabal: FUNEP, 1998.

DULBOIS, M. et al. Colorimetria method for determination of sugars and related substances. Analytical Chemistry, v. 28, n. 3, p. 350-356, 1956.

FARIA, E. V.; YOTSUYANAGI, K. Técnicas de análise sensorial. 2. ed. Campinas: ITAL, 2008.

FERNÁNDEZ-LÓPEZ, J. A. et al. Dependence between colour and individual anthocyanin content in ripening grapes. Food Research International, v. 31, n. 9, p. 667-672, 1998.

FOLEGATTI, M. I. S. et al. Aproveitamento industrial do umbu: processamento de geléia e compota. Ciência e Agrotecnologia, v. 27, n. 6, p. 1308-1314, 2003.

FOOD AND AGRICULTURE ORGANIZATION OF UNITED NATIONS - FAO. The State of Food Insecurity in the World. Roma: FAO, 2004. Disponível em: <ftp://ftp.fao.org/docrep/fao/007/ y5650e/y5650e00.pdf>. Acesso em: 13 jun. 2008.

GONDIM, J. A. M. et al. Composição centesimal e de minerais em cascas de frutas. Ciência e Tecnologia de Alimentos, v. 25, n. 4, p. 825-827, 2005. http://dx.doi.org/10.1590/S0101-20612005000400032

GONÇALVES, M. C. R. et al. Fibras dietéticas solúveis e suas frações nas dislipidemias. Revista Brasileira de Nutrição Clínica, v. 22, n. 2, p. 167-173, 2007.
GRANADA, G. G. et al. Caracterização física, química, microbiológica e sensorial de geléia light de abacaxi. Ciência e Tecnologia de Alimentos, v. 25, n. 4, p. 825-827, 2005.

GUERRA, N. B. et al. Modificações do método gravimétrico não enzimático para determinar fibra alimentar solúvel e insolúvel em frutos. Revista de Nutrição, v. 17, n. 1, p. 45-52, 2004.

JACKIX, M. H. Geléias e doces em massa. In: JACKIX, M. H. Doces, geléias e frutas em calda 2. ed. São Paulo: Editora da UNICAMP, 1988. cap. 7, p. 172.

JORGE, J. S.; MONTEIRO, J. B. R. O efeito das fibras alimentares na ingestão, digestão e absorção dos nutrientes. Nutrição Brasil, v. 4, n. 4, p. 218-229, 2005.

LABRUNA, J.C. Sucos prontos: matam a sede do mercado. Engarrafador moderno: revista de negócios e tecnologia em bebidas, v. 10, n. 84, p. 34-38, 2001.

LAGO, E. S.; GOMES, E.; DA-SILVA, R. Produção de geléia de jambolão (Syzygium cumini Lamarck): processamento, parâmetros físico-químicos e avaliação sensorial. Ciência e Tecnologia de Alimentos, v. 26, n. 4, p. 847-852, 2006. http://dx.doi.org/10.1590/ S0101-20612006000400021

LAUFENBERG, G.; KUNZ, B.; NYSTROEM, M. Transformation of vegetable waste into value added products: (A) the upgrading concept; (B) practical implementations. Bioresource Technology, v. 87, n. 2 , p. $167-198,2003$. http://dx.doi.org/10.1016/S09608524(02)00167-0

LICODIEDOFF, S. Influência do teor de pectinas comerciais nas características físico-químicas e sensoriais da geléia de abacaxi (Ananas comosus (L.) Merrill). 2008. 119f. Dissertação (Mestrado em Tecnologia de Alimentos) - Universidade Federal do Paraná, Curitiba, Paraná, 2008.

LORENZI, H. et al. Frutas brasileiras e exóticas cultivadas (de consumo in natura). São Paulo: Editora Plantarum, 2006.

LOUSADA JUNIOR, J. E. et al. Caracterização físico-química de subprodutos obtidos do processamento de frutas tropicais visando seu aproveitamento na alimentação animal. Ciência Agronômica, v. 37, n. 1, p.70-76, 2006.

LUZURIAGA, D. A.; BALABAN, M. O.; YERALAN, S. Analysis of visual quality attributes of white shrimp by machine vision. Journal of Food Science, v. 62, n. 1, p. 113-118, 1997. http://dx.doi. org/10.1111/j.1365-2621.1997.tb04379.x

MIGUEL, A. C. A. M. et al. Aproveitamento agroindustrial de resíduos sólidos provenientes do melão minimamente processado. Ciência e Tecnologia de Alimentos, v. 28, n. 3, p. 733-737, 2008. http:// dx.doi.org/10.1590/S0101-20612008000300033

MILLER, G. L. Use of dinitrosalicylic acid reagent for determination of reducing sugar. Analytical Chemistry, v. 31, n. 3, p. 426-428, 1959. http://dx.doi.org/10.1021/ac60147a030

MOTA, R. V. Caracterização física e química de geléia de amora-preta. Ciência e Tecnologia de Alimentos, v. 26, n. 3, p. 539-543, 2006. http://dx.doi.org/10.1590/S0101-20612006000300009

MOTA, R. V. Características químicas e aceitabilidade de geléias de amora-preta de baixo teor de sólidos solúveis. Brazilian Journal of Food Technology, v. 10, n. 2, p. 116-121, 2007.

NACHTIGALL, A. M. et al. Geléias light de amora-preta. Boletim CEPPA, v. 22, n. 2, p. 337-354, 2004.

NUNES, J. L. S. Perspectiva da fruticultura brasileira. AgroLink, 2009. Disponível em: <http://www.agrolink.com.br/biotecnologia/ NoticiaDetalhe. aspx?CodNoticia=86922>. Acesso em: 23 out. 2009.

OLIVEIRA, S. F. et al. Aproveitamento alternativo da casca do maracujá-amarelo (Passiflora edulis F. Flavicarpa) para produção 
de doce em calda. Ciência e Tecnologia de Alimentos, v. 22, n. 3 , p. 259-262, 2002.

OLIVEIRA et al. Avaliação de parâmetros de qualidade físico-químicos de polpas congeladas de acerola, cajá e caju. Ciência e Tecnologia de Alimentos, v. 19, n. 3, p. 326-332, 1999. http://dx.doi.org/10.1590/ S0101-20611999000300006

PINHEIRO, E. R. Pectina da casca do maracujá amarelo (Passiflora edulis flavicarpa): Otimização da extração com ácido cítrico e caracterização físico-química. 2007. 79 f. Dissertação (Mestrado em Ciência de Alimentos)-Universidade Federal de Santa Catarina, Santa Catarina, 2007.

PREGNOlATTO, W.; PREGNOLATTO, N. P. (Coord.) Normas analíticas do Instituto Adolfo Lutz: métodos químicos e físicos para análise de alimentos. 2. ed. São Paulo: Instituto Adolfo Lutz, 1985.

RIBEIRO, E. P.; SERAVALLI, E. A. G. Química de alimentos. São Paulo: Edgard Blücher, 2004.

ROCHA, S. A. et al. Fibras e lipídios em alimentos vegetais oriundos do cultivo orgânico e convencional. Revista Simbio-Logias, v. 1, n. 2, p. 1-9, 2008.

RODRIGUES, L. A. et al. Extração e quantificação de pectina em frutas tropicais e exóticas produzidas no Brasil. In: CONGRESSO BRASILEIRO DE CIÊNCIA E TECNOLOGIA DE ALIMENTOS, 21., 2008, Belo Horizonte. Anais... Belo Horizonte: Digital Media, 2008.

RODRIGUEZ-AMAYA, D. B. et al. Updated brazilian database on food carotenoids: factors affecting carotenoid composition. Critical Review. Journal of Food Composition and Analysis, v. 21, n. 6, p. 445-463, 2008. http://dx.doi.org/10.1016/j.jfca.2008.04.001

ROSSO, V. V. et al. Identificação de carotenóides em frutas exóticas. In: CONGRESSO BRASILEIRO DE CIÊNCIA E TECNOLOGIA DE ALIMENTOS, 21., 2008, Belo Horizonte. Anais... Belo Horizonte: Digital Media, 2008.
RUSS, W.; SCHNAPPINGER, M. Waste related to the food industry: a challenge in material loops. In: OREOPOLOU, V.; RUSS, W. (Ed.). Utilization of by-products and treatment of waste in the food industry. New York: Springer, 2007. cap. 1, p. 1-13.

SACRAMENTO, C. K.; SOUZA, F. X. Cajá (Spondias mombin L.). Jaboticabal: Funep, 2000.

SCHIEBER, A.; STINTZING, F. C.; CARLE, R. By-products of plant food processing as a source of functional compounds - recent developments. Trends in Food Science \& Technology, v. 12, n. 11, p. 401-413, 2001. PMid:21299575. http://dx.doi.org/10.1016/S09242244(02)00012-2

SILVA JUNIOR et al. Collecting, ex situ conservation and characterization of "cajá-umbu" (Spondias mombim x Spondias tuberosa) germ-plasm in Pernambuco State, Brazil. Genetic Resources and Crop Evolution, v. 51, n. 4, p. 343-349, 2004.

SOARES, E. C. et al. Desidratação da polpa de acerola (Malpighia emarginata D. C.) pelo processo "foam-mat". Ciência e Tecnologia de Alimentos, v. 2, n. 2, p. 164-170, 2001. http://dx.doi.org/10.1590/ S0101-20612001000200008

SOLER, M. P. Industrialização de Geléias: Processamento Industrial. Campinas: ITAL, 1991. (Manual Técnico, n. 7).

SOUSA, M. G. A. et al. Características físicas de frutos de cajarana (Spondias cythereae Sonn). Disponível em: <http://www. seminarioicuesc.com.br/sistema/resumos/11_pag143.PDF>. Acesso em: 13 ago. 2008.

SUZUKI, A. et al. Caracterização da composição centesimal e físicoquímicas de frutas tropicais. Disponível em: <http://www.usp.br/ siicusp/15Siicusp/4360.pdfrendimento>. Acesso em: 03 ago 2008.

UNIVERSIDADE DE CAMPINAS - UNICAMP. Tabela brasileira de composição de alimentos - TACO. versão 2. 2. ed. Campinas: UNICAMP/NEPA, 2006. Disponível em: <http://www.unicamp. br/nepa/taco/contar/tabela1_pdf.pdf $>$. Acesso em: 18 nov. 2007. 